\title{
Immunoreactivity of the $60 \mathrm{kDa}$ cysteine-rich proteins of Chlamydia trachomatis, Chlamydia psittaci and Chlamydia pneumoniae expressed in Escherichia coli
}

\author{
M. W. Watson, P. R. Lambden, J. S. Everson and I. N. Clarke \\ Author for correspondence: I. N. Clarke. Tel: +44703796975.
}

Molecular Microbiology, Faculty of Medicine, Southampton General Hospital, Southampton, so9 $4 X Y, U K$
The $60 \mathrm{kDa}$ cysteine-rich proteins (CrPs) of Chlamydia are developmentally regulated outer envelope proteins synthesized late in the chlamydial growth cycle. These proteins, found only on the extracellular infectious elementary bodies, elicit major antibody responses in chlamydial infection. We have cloned and expressed in Escherichia coli the complete $60 \mathrm{kDa}$ CrP genes from Chlamydia trachomatis, C. psittaci and C. pneumoniae. The recombinant products were expressed as either 'native' proteins or as fusions with the bacteriophage $\mathrm{I7}$ gene 10 protein. Electron microscopy showed that recombinant proteins were produced as insoluble inclusions within the $E$. coli host cells. The recombinant $60 \mathrm{kDa} C r P s$ were purified and used to raise high titre polyclonal antisera. In immunoblot analysis these antisera reacted with the $60 \mathrm{kDa}$ CrPs from purified elementary bodies of all three chlamydial species in a genus-specific manner. Further molecular analysis allowed the genus-specific cross-reacting epitopes to be localized by using overlapping synthetic peptides covering the $C$. trachomatis $60 \mathrm{kDa}$ CrP. Immunogold labelling experiments using purified infectious elementary bodies from the three chlamydial species indicated that the $60 \mathrm{kDa}$ CrPs are not surface accessible to antibody binding.

Keywords: Chlamydia spp., cysteine-rich proteins, epitope, envelope proteins

\section{INTRODUCTION}

Three of the four recognized species of Chlamydia are human pathogens. Cblamydia pneumoniae is a recently defined human pathogen responsible for acute respiratory infections. Cblamydia psittaci infects a diverse range of host species and is a well known opportunistic pathogen in man causing mainly respiratory infections. Chlamydia trachomatis infections in humans are caused by two biovariants (biovars). The trachoma biovar infects mucosal epithelia of the eye and genital tract producing localized disease; the lymphogranuloma venereum biovar (LGV) infects mucosal genital epithelia but also causes more invasive disease.

Members of the genus Chlamydia have a unique intracellular life cycle which involves an infectious electron

\footnotetext{
Abbreviations: $\mathrm{CrP}$, cysteine-rich protein; MOMP, major outer membrane protein; EB, elementary body; RB, reticulate body; LGV, lymphogranuloma venereum biovar.
}

dense elementary body (EB) and a replicative, noninfectious metabolically active reticulate body (RB). Chlamydia are Gram-negative bacteria but do not possess a defined peptidoglycan layer. The structural stability of the EB cell wall, in the absence of peptidoglycan, has been attributed to a unique set of cysteine-rich outer envelope proteins (Bavoil et al., 1984). The EB outer envelope comprises the cysteine-rich major outer membrane protein (MOMP) and two additional cysteine-rich proteins (CrPs) of approximately 60 and $12 \mathrm{kDa}$ molecular mass. The $12 \mathrm{kDa} \mathrm{CrP}$ has recently been shown to be an acylated protein translated from a short open reading frame of 88 amino acids (Everett \& Hatch, 1991). Primer extension and Northern blot studies have shown the $C$. trachomatis $\mathrm{L} 160 \mathrm{kDa} \mathrm{CrP}$ is closely linked on the chromosome to the gene for the $12 \mathrm{kDa}$ lipid-modified $\mathrm{CrP}$. Both open reading frames are transcribed together as a single operon and their expression is tightly synchronized with the chlamydial growth cycle, with maximum transcription occurring late in the growth cycle as RBs condense to form infectious EBs (Lambden $e t$ al., 1990). 
Both the $60 \mathrm{kDa} \mathrm{CrP}$ and the lipid-modified $12 \mathrm{kDa} \mathrm{CrP}$ can be extracted in a highly cross-linked form only ftom EBs. The MOMP, which is found in both EBs and RBs, is thought to act as a porin (Bavoil et al., 1984) and has a role in the attachment and uptake of EBs by host cells. It is also recognized as an exposed surface molecule possessing infection-neutralizing epitopes (Collett et al., 1989; Zhang et al., 1989; Conlan et al., 1989; Conlan et al., 1990; Peterson et al., 1990). Polyacrylamide gel analvsis of C. trachomatis proteins has shown that the $60 \mathrm{kDa} \mathrm{CrP}$ occurs as a singlet in the trachoma biovar and as a $60 / 62 \mathrm{kDa}$ doublet in the LGV biovar (Batteiger et al., 1985). The C. trachomatis $60 / 62 \mathrm{kDa}$ doublet appears to undergo two-site post-translational processing of its amino terminal signal peptide (Allen \& Stephens, 1989). Only the $C$. psittaci avian isolate $6 \mathrm{BC}$ has been subjected to detailed analysis of its $60 \mathrm{kDa}$ CrPs. This isolate, which is closely related to the $C$. psittaci strain used in our study, produces a $60 / 62 \mathrm{kDa}$ doublet (Hatch et al., 1984; Hatch et al., 1986). In C. pneumoniae strain AR-39 the $60 \mathrm{kDa}$ CrPs also occur as a doublet (Melgosa et al., 1993). The complete nucleotide sequence of the $60 \mathrm{kDa} \mathrm{CrP}$ genes has been determined for ten chlamydial strains: $C$. trachomatis serovars LGV1 (Clarke et al., 1988), LGV2 (Allen \& Stephens, 1989), LGV3, E (strain Bour), C (De La Maza et al., 1991), B (Watson et al., 1989), E (strain DK20) (Coles et al., 1990); C. psittaci avian strains EAE A/22M (Watson et al., 1990a), 6BC (Everett \& Hatch, 1991); C. pneumoniae IOL 207 (Watson et al., 1990b). The evolutionary relationships of these sequences have been analysed and a phylogenetic tree for chlamydia proposed (Fitch et al., 1993) which shows three distinct arms each representing the $C$. trachomatis, $C$. psittaci and C. pneumoniae species.

Major antibody responses to $60 \mathrm{kDa}$ proteins in chlamydial infection have been reported (Newhall et al., 1982; Batteiger \& Rank, 1987; Brunham et al., 1987; Wagar et al., 1990). Preliminary studies using lactoperoxidase-catalysed radioiodination of EBs suggested the $60 \mathrm{kDa} \mathrm{CrP}$ might be surface exposed (Batteiger et al., 1985; Newhall et al., 1982). These observations coupled to the higher net positive charge seen for the LGV biovar and C. psittaci $60 / 62 \mathrm{kDa}$ (doublet) CrPs compared to the singlet $60 \mathrm{kDa} \mathrm{CrP}$ from trachoma biovars of $C$. trachomatis have led to the suggestion that this set of proteins may have a role in enhancing chlamydial attachment to host cells (Batteiger et al., 1985). Other workers have suggested, on purely hypothetical grounds, that the $60 \mathrm{kDa} \mathrm{CrP}$ might be associated with the cytoplasmic face of the inner membrane (Everett \& Hatch, 1991).

In the only experimental study of $60 \mathrm{kDa} \mathrm{CrP}$ epitope localization, surface exposure of the C. trachomatis $60 \mathrm{kDa}$ CrPs was not demonstrated (Collett et al., 1989). However, this study was limited because it used three relatively uncharacterized monoclonal antibodies to the $60 \mathrm{kDa}$ $\mathrm{CrP}$, and a single polyclonal mouse antiserum of undefined molecular specificity.

Thus, despite extensive serological surveys, the role of the $60 / 62 \mathrm{kDa} \mathrm{CrPs}$ in human immunity to chlamydial infection remains unresolved. Also it is still unclear whether these proteins are surface exposed on EBs (Fitch et al., 1993). Therefore, the purpose of this work was to investigate the immunoreactivity of the chlamydial $60 \mathrm{kDa}$ CrPs. Our approach was to attempt expression in E. coli of the intact $60 / 62 \mathrm{kDa} \mathrm{CrP}$ from C. trachomatis, $C$. psittaci and $C$. pneumoniae to obtain recombinant $60 \mathrm{kDa}$ CrPs free from all other chlamydial proteins. These products could then be used to prepare mono-specific high titre polyclonal antisera to the $60 \mathrm{kDa}$ CrPs. We wished to use these resources to perform a comprehensive analysis of the immunological relationships between the $60 \mathrm{kDa}$ CrPs from the three chlamydial species and also to address the important unresolved question of $60 \mathrm{kDa} \mathrm{CrP}$ surface localization by immunogold labelling of purified EBs from all three chlamydial species.

\section{METHODS}

Organisms. C. trachomatis serovar B (strain B/Jali 20/OT), C. psittaci (strain EAE A22/M) and C. pneumoniae (strain IOL 207) were grown and purified as described previously (Salari \& Ward, 1981; Carter et al., 1991). The C. psittaci strain has been described by Pickett et al. (1988). Chlamydia were stored at $-80^{\circ} \mathrm{C}$ to preserve their structure and viability. E. coli strain K12 JM109 was used for all genetic manipulation work.

Oligonucleotide synthesis and PCR reactions. Oligonucleotides for use as sequencing or polymerase chain reaction (PCR) primers were synthesized on a model $381 \mathrm{~A}$ automated DNA synthesizer (Applied Biosystems) using $\beta$ cyanoethyl phosphoramidite chemistry. PCR reactions were performed in a Perkin-Elmer Cetus DNA thermal cycler. The reaction conditions were as recommended by Perkin-Elmer Cetus; $\mathrm{KCl} 50 \mathrm{mM}$; $10 \mathrm{mM}$ Tris/ $\mathrm{HCl}$ (pH 8.8); $\mathrm{MgCl}_{2} 15 \mathrm{mM}$; Triton X-100 $1 \%(\mathrm{v} / \mathrm{v}) ; 0.2 \mathrm{mM}$ each dNTP; $1 \mu \mathrm{M}$ each primer; $10-100 \mathrm{ng}$ template DNA; $1-2.5$ units of Taq DNA polymerase.

Molecular cloning of the $60 \mathrm{kDa} \mathrm{CrP}$ genes for expression in $\boldsymbol{E}$. coli. The recombinant plasmids used in this study together with details of their expressed products are summarized in Table 1. The entire $60 \mathrm{kDa} \mathrm{CrP}$ gene of $C$. trachomatis serovar B/Jali$20 / \mathrm{OT}$ was sub-cloned as a $1.8 \mathrm{kbp} S$ peI fragment from the pBluescript vector ( $\mathrm{PJ} 3 \mathrm{~B}$ ) described by Watson et al. (1989) into a modified pGEMEX 1 vector (Promega). Plasmid pGEMEX1 was modified by insertion of a SpeI restriction site (TCGAGACTAGTC) at the XhoI site to form vector pGEMSPE. Plasmid clones in both possible orientations [pJGEM(a), positive orientation for expression and pJGEM(b), inverse orientation] were identified using restriction endonuclease digestion with $X b a \mathrm{I}$ and agarose gel electrophoresis.

A $2.95 \mathrm{kbp} \mathrm{XbaI} \mathrm{genomic} \mathrm{fragment} \mathrm{containing} \mathrm{the} 60 \mathrm{kDa} \mathrm{CrP}$ of C. psittaci (Watson et al., 1990a) was cloned into the XbaI site of pBluescript SK - using the $\lambda$ Zap II vector system (Stratagene) to yield recombinant plasmids pPS8C (Fig. 1b) and the opposite orientation insert pPS9C.

A $60 \mathrm{kDa}$ CrP gene cassette from C. pneumoniae was generated by PCR using two synthetic, restriction-site-containing oligonucleotides, IOLNXho (5'ACCCAAATCTCGAGGGTAAGAGTTTACAAA3') and IOLCXba (5'TATCGCTCTGCTCTAGAATAATTCCTTAGA3'), based on the sequences described by Watson et al. (1990b). The $60 \mathrm{kDa} \mathrm{CrP}$ gene was amplified from genomic DNA of IOL-207, repaired with T4 DNA polymerase and ligated into $S m a \mathrm{I}$ cut, dephosphorylated pSP73 (Promega) and transformed into E. coli JM109 to give 
Table 1. Recombinant plasmids

\begin{tabular}{|c|c|c|c|}
\hline Source of DNA & $\begin{array}{l}\text { Recombinant } \\
\text { plasmid }\end{array}$ & Host vector & $\begin{array}{l}\text { Expression of } \\
\text { recombinant protein }\end{array}$ \\
\hline C. trachomatis & pJ3B & pBlueScript & None \\
\hline C. psittaci & pPS8C & pBlueScript & 'Native' 60 kDa CrP \\
\hline C. trachomatis & pJGEM & $\begin{array}{l}\text { pGEMEX-1 } \\
\text { (SpeI linker) }\end{array}$ & Gene $1060 \mathrm{kDa}$ CrP fusion \\
\hline C. pneumoniae & pPUNAT & $\mathrm{pSP} 73$ & 'Native' $60 \mathrm{kDa} \mathrm{CrP}$ \\
\hline C. pneumoniae & pPUGEM & pGEMEX-1 & Gene $1060 \mathrm{kDa} \mathrm{CrP}$ fusion \\
\hline
\end{tabular}

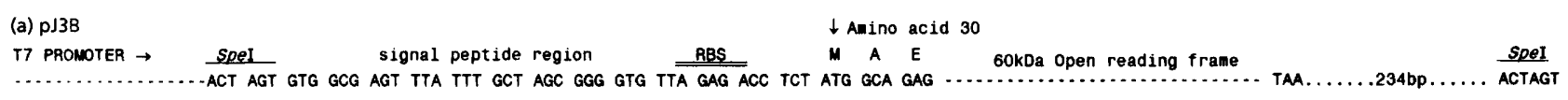

(b) PPS8C

T7 PROMOTER $\rightarrow$

XbaI

$\underset{\text { ATAGGAGATCCCT ATG TCC AAA }}{\text { RBS }}$

60kOa Open reading frame

TAA.....1.1kbp....... XCTAGI

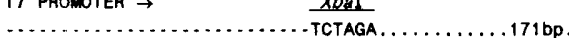

6okoa open reading frame

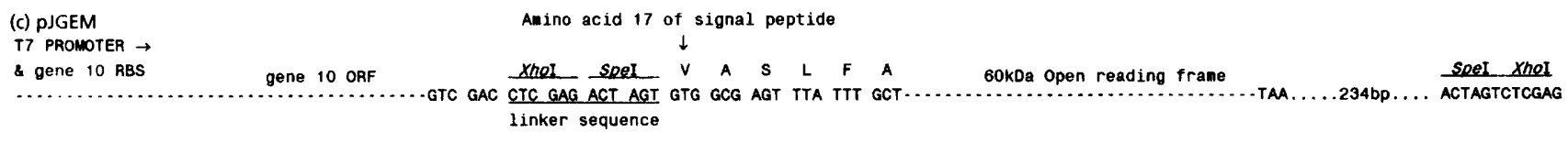

(d) PPUNAT

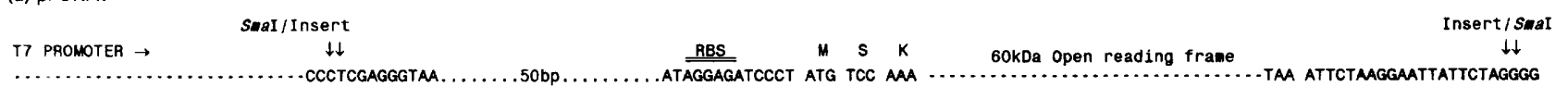

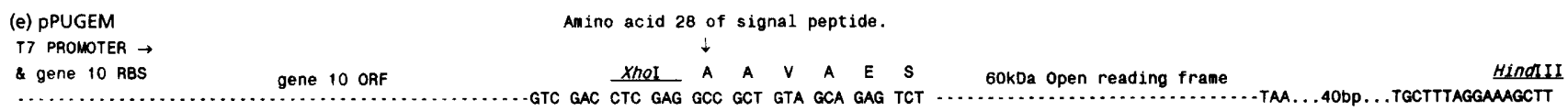

Fig. 1. Molecular details of recombinant plasmids. (a) C. trachomatis pJ3B (in pJ4B the $1.8 \mathrm{kbp}$ Spel insert is in the opposite orientation), (b) C. psittaci pPS8C (pPS9C opposite orientation), (c) C. trachomatis pJGEM, (d) C. pneumoniae pPUNAT, (e) C. pneumoniae pPUGEM.

pPUNAT (Fig. 1d). The C. pneumoniae $60 \mathrm{kDa}$ CrP was also expressed as a fusion protein in pGEMEX1. Synthetic oligonucleotides were used to generate a PCR product containing the $C$. pneumoniae $60 \mathrm{kDa} \mathrm{CrP}$ gene flanked by suitable restriction sites. The oligonucleotides used were IOLFNXho $\left(5^{\prime} \mathrm{CTT}\right.$ TGCCAGCGGGGGTCTCGAGGCCGCTGT3') and IOLFCXhoHind (5'CTCGAGCGGTACT'TCTT'TGAAAGCTT'TCCTAAA $3^{\prime}$ ). The PCR fragment was digested with $X b 0 \mathrm{I}$ and HindIII, purified by Geneclean and ligated into XboI/HindIII cut, dephosphorylated pGEMEX1 (Promega) to give pPLGEM (Fig. 1e).

Freshly transformed E. coli containing appropriate expression vectors were grown to an $\mathrm{OD}_{600}$ of 0.5 in Luria broth containing $100 \mu \mathrm{g}$ ampicillin $\mathrm{ml}^{-\mathbf{1}}$ before addition of isopropyl $\beta$-Dthiogalactoside (IPTG) to a final concentration of $5 \mathrm{mM}$. The culture was grown with shaking for a further $3 \mathrm{~h}$, after which the cells were harvested by centrifugation at $4000 \mathrm{~g}$. Cells were used immediately and assessed by SDS-PAGE for expression of $60 \mathrm{kDa}$ CrPs.
Preparation of $\boldsymbol{E}$. coli outer membranes. E. coli outer membranes were prepared essentially by the method of Osborn \& Munson (1974). Briefly, spheroplasts were lysed and after removal of cell debris by low speed centrifugation, the supernatant was centrifuged at $100000 \mathrm{~g}$ for $2 \mathrm{~h}$. The resultant membrane pellet was resuspended in $2 \mathrm{ml}$ cold $25 \%$ (w/v) sucrose $/ 5 \mathrm{mM}$ EDTA, pH $7 \cdot 5$, and layered onto a $55 \%$ to $30 \%$ sucrose step gradient and centrifuged at $100000 \mathrm{~g}$ for $18 \mathrm{~h}$. Gradient fractions containing outer membranes were collected and assayed for protein using the bicinchoninic acid technique (Smith et al., 1985).

Purification of inclusion bodies. A $250 \mathrm{ml}$ culture of recombinant $E$. coli was induced, harvested by centrifugation and resuspended in $15 \mathrm{ml}$ TAS, a mixture of Tris/acetate $(10 \mathrm{mM})$, sucrose $(0.75 \mathrm{M})$ and sodium azide $(0.05 \%)$ on ice. Lysozyme $(20 \mathrm{mg})$ was added and the bacteria stirred gently for $5 \mathrm{~min}$ before addition of $30 \mathrm{ml} 1.5 \mathrm{mM} \mathrm{EDTA} \mathrm{(pH} \mathrm{7.5).}$ Resultant spheroplasts were lysed by sonication and cell debris removed by centrifugation at $4000 \mathrm{~g}$ for $10 \mathrm{~min}$. Inclusion 
bodies were sedimented by centrifugation at $10000 \mathrm{~g}$ for $15 \mathrm{~min}$ and washed in $20 \mathrm{ml}$ TAS containing $5 \%$ Triton X-100. 'The pellet of inclusion bodies was resuspended in $5 \mathrm{ml}$ freshly prepared sodium azide $(0.05 \%) /$ phenylmethylsulphonylfluoride $(1 \mathrm{mM}) /$ EDTA $(1 \mathrm{mM})$. Where required inclusion bodies were further purified by preparative SDS-PAGE. Protein bands were recovered by electroelution into TE buffer, containing Tris/ $\mathrm{HCl}(10 \mathrm{mM}, \mathrm{pH} 7 \cdot 5)$ and EDTA $(1 \mathrm{mM}, \mathrm{pH} 8.0)$. Eluted protein was precipitated by dialysis against saturated ammonium sulphate and pelleted by centrifugation at $12000 \mathrm{~g}$ for $5 \mathrm{~min}$.

Antisera. A pool of monoclonal antibodies to the $60 \mathrm{kDa} \mathrm{CrP}$ of C. trachomatis (Newhall \& Basinski, 1986) were obtained from Dr J. Newhall (CDC, Atlanta, GA, USA) for use as immunoblotting probes.

Polyclonal antisera to the recombinant $60 \mathrm{kDa}$ CrPs from $C$. psittaci, C. trachomatis and C. pneumoniae were raised in female New Zealand White rabbits. Pre-immune serum was obtained from each animal followed by subcutaneous immunization on day one with $100 \mu \mathrm{g}$ protein in Freund's complete adjuvant and subsequent immunizations with $100 \mu \mathrm{g}$ protein in Freund's incomplete adjuvant on days $15,29,43,57,67,71$ and 85 . Antisera were raised to the following recombinant proteins: $C$. pneumoniae $60 \mathrm{kDa} \mathrm{CrP}$ 'native protein'; C. trachomatis $60 \mathrm{kDa}$ $\mathrm{CrP}$ 'fusion protein'; C. pneumoniae $60 \mathrm{kDa} \mathrm{CrP}$ fusion proteir: C. psittaci $60 \mathrm{kDa} C r P$ native protein; $\mathrm{T} 7$ gene 10 protein; E. coli JM109/DE3 total cell extract. Cross-reacting antibodies were removed by adsorption with proteins obtained from sonic extracts of E. coli JM109/DE3.

SDSPAGE and immunodetection of proteins. SDS-PAGE was performed using the discontinuous buffer system method of Laemmli (1970) with $10 \%$ acrylamide gels (acrylamide: bisacrylamide 38:5:1, w/w). Electroblotting to nitrocellulose sheets was performed in transfer buffer containing, Tris/HCl $(25 \mathrm{mM})$, glycine $(192 \mathrm{mM})$, SDS $(0 \cdot 1 \%, \mathrm{w} / \mathrm{v})$ and methanol $(20 \%, \mathrm{v} / \mathrm{v})$ using a Trans-Blot SD 'semi-dry' blotter (Bio-Rad). Following blotting the nitrocellulose membrane was washed in TTBS blocking solution, containing TBS $[\mathrm{NaCl}$ $(0.5 \mathrm{M})$ and Tris $/ \mathrm{HCl}(20 \mathrm{mM}) ; \mathrm{pH} 7.5]$ and Tween-20 $(0.05 \%$, $\mathrm{v} / \mathrm{v}$ ) at $22{ }^{\circ} \mathrm{C}$. The blocking solution was discarded and primary antibody $(1 / 200)$ in TTBS $/ 1 \%(\mathrm{w} / \mathrm{v})$ dried skimmed milk (Marvel) was added to the tube $(10 \mathrm{ml})$ for between 2 and $16 \mathrm{~h}$. After washing in TTBS, membranes were treated with the secondary antibody-alkaline phosphatase conjugate. Alkaline phosphatase-antibody conjugates were detected using a BCIP/NBT (bromochloroindolyl phosphate/nitroblue tetrazolium salt) redox chromogenic reaction catalysed by alkaline phosphatase in a carbonate buffer $\left(\mathrm{NaHCO}_{3}\right.$, $0.1 \mathrm{mM} / \mathrm{MgCl}_{2}, 1.0 \mathrm{mM}$; $\left.\mathrm{pH} 9.8\right)$. Greater sensitivity was achieved when micellular $\left[3^{\prime}-\left(2^{\prime}\right.\right.$-spiroadamantane)-4-methoxy4-( 3 'phosphoryloxy)-phenyl-1,2-dioxetane]AMPPD (Lumiphos; Cambridge Research Biochemicals) was used to detect bound alkaline phosphatase.

Solid phase peptides and epitope mapping. Solid phase peptides were synthesized on polyethylene pegs using the method of Geysen et al. (1987). A nested set of overlapping (five residues) solid phase synthetic peptides (decamers) covering the entire sequence of the mature $60 \mathrm{kDa} \mathrm{CrP}$ of $C$. trachomatis serovar L1 were constructed in duplicate on polyethylene pegs. Pegs were blocked in 'supercocktail' a mixture containing $1 \%$ (w/v) ovalbumin (Sigma, grade II) and $1 \%(\mathrm{w} / \mathrm{v})$ BSA in TPBS $\left(0.145 \mathrm{M} \mathrm{NaCl} / 60 \mathrm{mM} \mathrm{Na} \mathrm{HPO}_{4} / 28 \mathrm{mM} \mathrm{NaH} \mathrm{PO}_{4} / 0.05 \%\right.$ $(\mathrm{w} / \mathrm{v})$ Tween-20; $\mathrm{pH} 7 \cdot 4)$ in 96 -well microtitre plates $(150 \mu \mathrm{l}$ per well) for $2 \mathrm{~h}$ at room temperature. Rabbit antisera were diluted $1: 300$ in 'supercocktail' and reacted with the pegs overnight at $4{ }^{\circ} \mathrm{C}$. Unbound antibody was removed with four 10 min washes in $1 \times$ TPBS. Immunoreactive peptides were detected by treatment with goat anti-rabbit horse radish peroxidase conjugate and colour development in flat-bottomed microtitre plates using $150 \mu \mathrm{l}$ ABTS substrate, containing $\mathrm{Na}_{2} \mathrm{HPO}_{4}$ $(0 \cdot 1 \mathrm{M})$, citric acid $(0 \cdot 08 \mathrm{M}, \mathrm{pH} 4 \cdot 0)$, ABTS [2,2'-azino-di(3ethylbenz-thiazoline sulphonic acid)] (Sigma, $0.5 \mathrm{mg} \mathrm{ml}^{-1}$ ) and $\mathrm{H}_{2} \mathrm{O}_{2}$ (120 vol., $0.3 \mu \mathrm{ml}^{-1}$ ) per well. Absorbance was monitored at $402 \mathrm{~nm}$ in a Titertek Twinreader colorimeter (Flow Laboratories). Trays of pegs were processed for further rounds of ELISA by sonication for $30 \mathrm{~min}$ at $60^{\circ} \mathrm{C}$ in disruption buffer containing $\mathrm{NaH}_{2} \mathrm{PO}_{4}(0 \cdot 1 \mathrm{M})$, 2-mercaptoethanol $(0 \cdot 1 \%$, $\mathrm{v} / \mathrm{v})$ and $\operatorname{SDS}(1 \%, \mathrm{w} / \mathrm{v}), \mathrm{pH} 7 \cdot 2$, using a Camlab Transsonic $\mathrm{T} 700 / \mathrm{H}$ sonicator to remove bound antibody. Disruption buffer was removed by four washes with $60^{\circ} \mathrm{C}$ water before placing the peg trays into boiling methanol for $2 \mathrm{~min}$. Pegs were then air dried and stored desiccated at $4{ }^{\circ} \mathrm{C}$ or blocked immediately for another round of ELISA.

Electron microscopy. E. coli cells expressing the chlamydial $60 \mathrm{kDa} \mathrm{CrPs}$ were examined by electron microscopy as described by Pickett $e$ t al. (1988). For immunogold studies purified elementary bodies were incubated with rabbit antisera at $37{ }^{\circ} \mathrm{C}$ for $1 \mathrm{~h}$. Unbound antibody was removed by three washes with TBS. EBs were then resuspended in $50 \mu \mathrm{l}$ of a 1 in 25 dilution of protein-G-gold conjugate (15 nm particle size; BioCell) in TBS and incubated at $37^{\circ} \mathrm{C}$ for $1 \mathrm{~h}$. Unbound gold conjugate was removed by washing in TBS and the EBs resuspended in $50 \mu$ water. Drops of EB suspensions $(5 \mu \mathrm{l})$ were placed on nickel Formvar electron microscopy grids coated with poly-lysine. The grids were blotted dry and viewed using a Hitachi H7000 transmission electron microscope.

\section{RESULTS AND DISCUSSION}

\section{Molecular cloning and expression of chlamydial $60 \mathrm{kDa}$ CrPs}

We have previously encountered problems of stability when cloning the amino terminus of the $60 \mathrm{kDa} C r P$ gene of C. trachomatis L1 into plasmid vectors (Clarke \& Lambden, 1988). Thus our alternative approach was to attempt high level expression of the $60 \mathrm{kDa} C r P s$ of $C$. trachomatis (B/Jali 20/OT) serovar B as a fusion protein using the tightly regulated pGEMEX vector system (Promega). In this system recombinant proteins are fused to the bacteriophage T7 capsid gene 10 protein and are under control of the T7 RNA polymerase promoter (Studier \& Moffatt, 1989). The C. trachomatis serovar B $60 \mathrm{kDa}$ CrP had previously been shown by Southern blot and sequence analysis to be almost entirely contained within a $1.8 \mathrm{kbp} S p e I$ restriction endonuclease fragment (Watson et al., 1989) which was cloned in pBluescript to give pJ3B (Fig. 1a). This DNA fragment, missing only the $5^{\prime}$ terminal $48 \mathrm{bp}$ of the $60 \mathrm{kDa} \mathrm{CrP}$ open reading frame, was ligated into the modified pGEMEX vector pGEMSPE to generate pJGEM (Fig. 1c).

Southern blotting and restriction analysis of chromosomal DNA purified from C. psittaci EAE A22/M indicated that the $60 \mathrm{kDa} \mathrm{CrP}$ gene was located on a unique $2.95 \mathrm{kbp}$ $X b a \mathrm{I}$ restriction endonuclease fragment (data not shown). This DNA fragment was cloned into the $\mathrm{Xbal}$ site of $\lambda \mathrm{ZAP}$ II and released as a pBluescriptSK ${ }^{-}$recombinant plasmid pPS8C (Fig. 1b) as an intermediate sub-cloning step. Surprisingly, gel analysis of the recombinant proteins (Fig. 2a) indicated expression of the $60 \mathrm{kDa} \mathrm{CrP}$ 

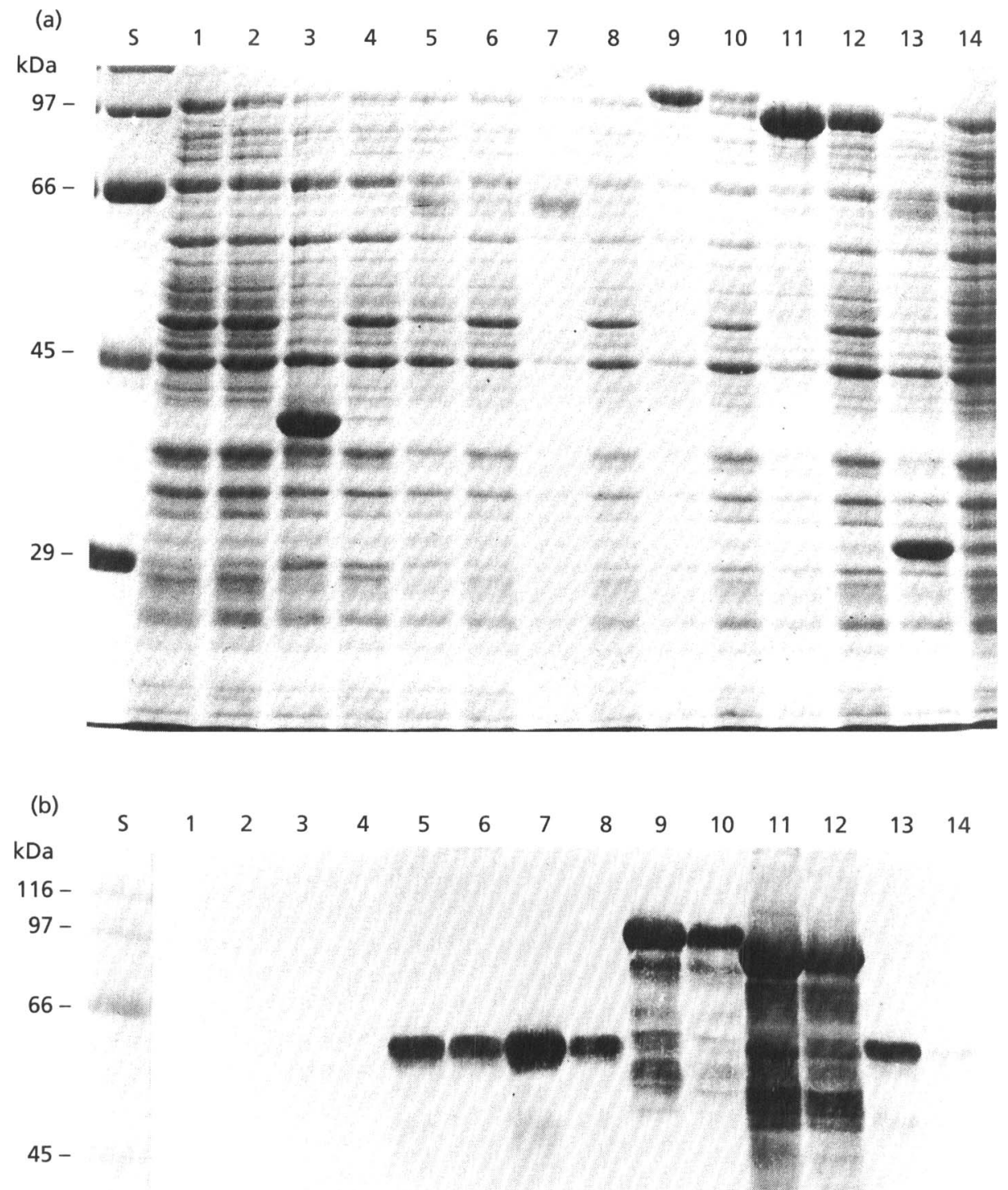

$29-$

Fig. 2. (a) PAGE blue-stained SDS-polyacrylamide gel (10\%) of $E$. coli proteins extracted from various expressing recombinants. Lanes: 1, E. coli JM109 (DE3) induced with IPTG; 2, E. coli JM109 (DE3) uninduced; 3, pGEMEX1 in JM109 (DE3) induced with IPTG; 4, pGEMEX 1 in $3 M 109$ (DE3) uninduced; 5, pPS9C in JM109 (DE3) induced with IPTG; 6, pPS9C in JM109 (DE3) uninduced; 7, pPS8C in JM109 (DE3) induced with IPTG; 8, pPS8C in JM109 (DE3) uninduced; 9, pPUGEM in JM109 (DE3) induced with IPTG; 10, pPUGEM in JM109 (DE3) uninduced; 11, pJGEM in JM109 (DE3) induced with IPTG; 12, pJGEM in JM109 (DE3) uninduced; 13, pPUNAT in JM109 (DE3) induced with IPTG; 14, pPUNAT in JM109 (DE3) uninduced; S, standard molecular mass markers. (b) Immunoblot of a duplicate gel to (a) with identical lane loading order. Molecular mass standards on blots were stained with amido black. A pool of monoclonal antibodies to $C$. trachomatis $60 \mathrm{kDa}$ CrPs (Newhall \& Basinski, 1986) was used to detect expressed recombinant proteins. 

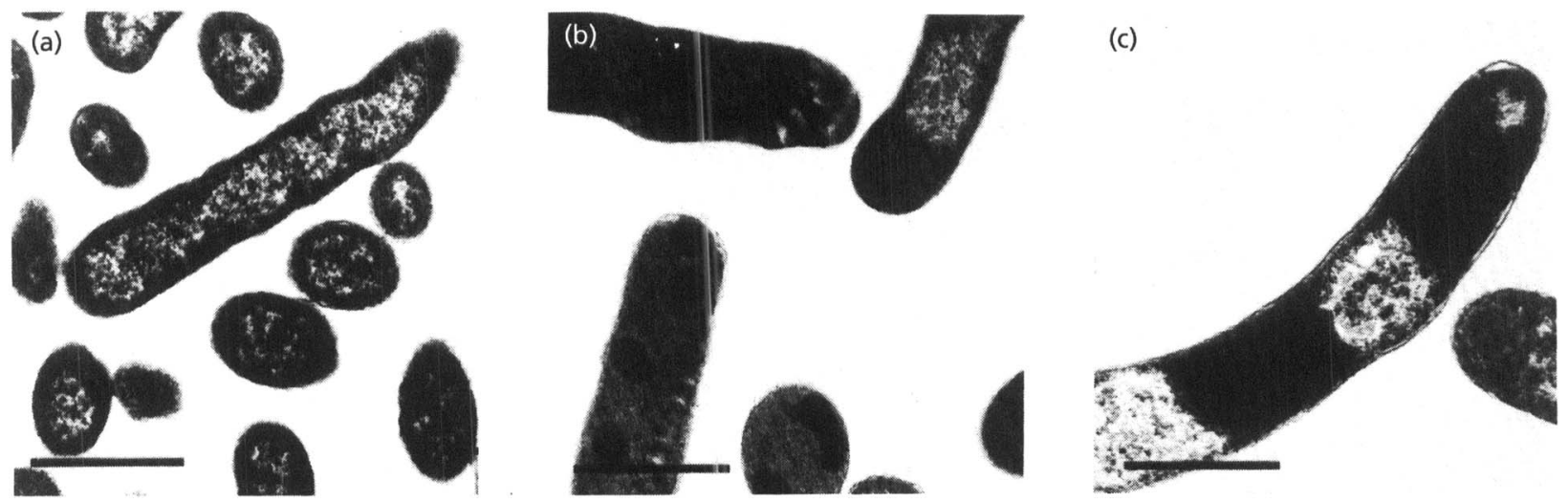

Fig. 3. Transmission electron micrographs of inclusion bodies seen in IPTG-induced E. coli [JM109 (DE3)]. (a) no plasmid, (b) pPS8C (Chlamydia psittaci, native $60 \mathrm{kDa}$ CrP), (c) pJGEM (Chlamydia pneumoniae, gene 10-60 kDa CrP fusion protein). Bar, $2 \mu \mathrm{m}$.

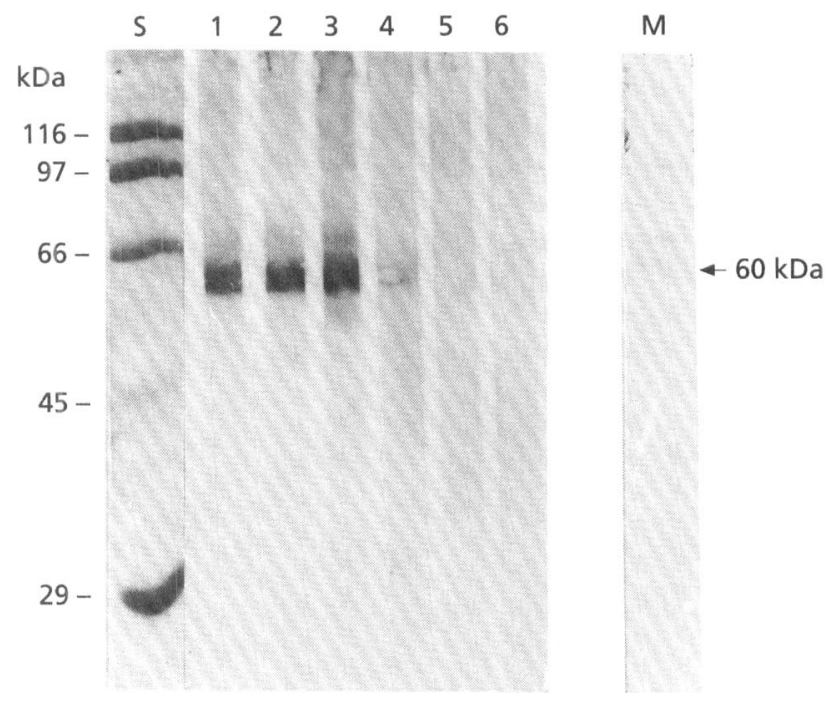

Fig. 4. C. pneumoniae purified EBs separated by SDS-PAGE and probed with antisera against (lanes): $1, C$. psittaci, native $60 \mathrm{kDa} \mathrm{CrP} ; 2$, C. pneumoniae, native $60 \mathrm{kDa} \mathrm{CrP} ; 3, \mathrm{C}$. pneumoniae, gene 10-60 kDa CrP fusion; 4, C. trachomatis, gene 10-60 kDa CrP fusion; 5, control E. coli JM109 (DE3); 6, control E. coli JM109 (DE3) containing pGEMEX-1. Lane S, amido black stained molecular mass markers; Lane $M, C$. pneumoniae EBs separated on a different gel and probed with the pool of $60 \mathrm{kDa}$ CrP monoclonal antibodies (Newhall \& Basinski, 1986).

from both $\mathrm{T} 7$ and lac promoters for the two possible orientations of the insert ( $\mathrm{PPS} 8 \mathrm{C}$ and $\mathrm{pPS} 9 \mathrm{C}$ ).

The $C$. pneumoniae $60 \mathrm{kDa} \mathrm{CrP}$ gene did not have useful restriction endonuclease cleavage sites for cloning; therefore a pair of oligonucleotide primers based on the published flanking nucleotide sequences of the $C$. pneumoniae $60 \mathrm{kDa} \mathrm{CrP}$ gene (Watson et al., 1990b) were used in the PCR to generate a $60 \mathrm{kDa} \mathrm{CrP}$ gene cassette. The PCR product was ligated into the SmaI site of the cloning vector pSP73 to give pPUNAT (Fig. 1d). This construct under control of the T7 promoter expressed the $60 \mathrm{kDa} \mathrm{CrP}$ at approximately half the levels of the $C$. psittaci recombinant (pPS8C) as judged by SDS-PAGE. In order to increase expression of the $C$. pneumoniae $60 \mathrm{kDa} \mathrm{CrP}$ a second pair of primers were synthesized. These primers incorporate unique $X h o I$ and HindIII restriction sites to facilitate directional cloning of the PCR products into pGEMEX 1 to give pPUGEM (Fig. 1e).

High level expression of the $60 \mathrm{kDa} \mathrm{CrP}$ was achieved for all of the chlamydial species as assessed by gel analysis of total cell proteins (Fig. 2a). Growth curves for all recombinants showed a significant reduction in growth rates following induction with IPTG (data not shown). Interestingly, recombinant bacteria expressing the $C$. psittaci $60 \mathrm{kDa} \mathrm{CrP}$ (pPS9C) clumped on induction with IPTG (as visualized by phase contrast microscopy), causing a rapid reduction in optical density of the culture supernatant.

\section{Properties of recombinant $60 \mathrm{kDa}$ CrPs}

Comparison of the deduced amino acid sequence from the C. psittaci $60 \mathrm{kDa} \mathrm{CrP}$ of strain $6 \mathrm{BC}$ and the $60 \mathrm{kDa} \mathrm{CrP}$ EAE/A22/M used in this study has shown only two amino acid differences (Everett \& Hatch, 1991). The intact $60 \mathrm{kDa} \mathrm{CrP}$ from $C$. psittaci $6 \mathrm{BC}$ was expressed in E. coli and was reported to form a doublet, leading to the suggestion that it had undergone two-site posttranslational cleavage (Everett \& Hatch, 1991). The implication of this observation is that the protein was processed in a similar manner to its native chlamydial host and was located to the E. coli cell envelope. We were therefore interested to see if the two intact recombinant $60 \mathrm{kDa}$ CrPs were transported to the E. coli cell envelope. Localization to the outer membrane may alter cell surface properties which could account for the aggregation of cells seen in the recombinant containing PPS9C after induction with IPTG.

E. coli cell envelope preparations were purified from each recombinant expressing chlamydial $60 \mathrm{kDa} \mathrm{CrPs}$. The outer membrane preparations were analysed by polyacrylamide gel electrophoresis and showed the expected E. coli outer membrane proteins and LPS but no 

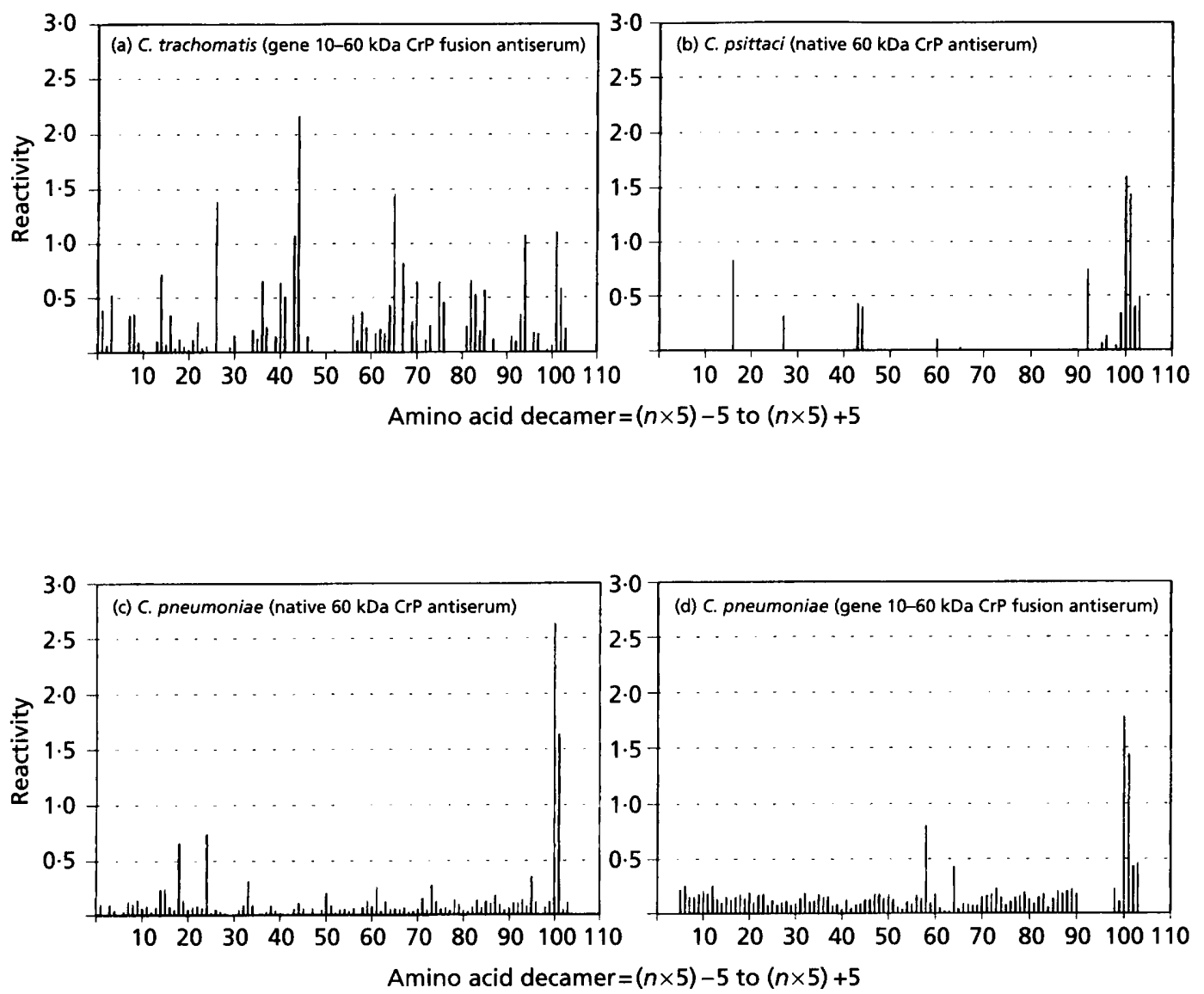

Fig. 5. Reactivity of polyclonal $60 \mathrm{kDa} \mathrm{CrP}$ antisera with solid phase peptides of the $60 \mathrm{kDa} \mathrm{CrP}$ of $\mathrm{C}$. trachomatis. Antisera are indicated at the top of each chart. The reactivities are the mean of two duplicate reactions with reactivities of preimmune serum subtracted [in all cases pre-immune serum and serum raised to $E$. coli JM109 (DE3) containing the bacteriophage 77 gene 10 capsid protein showed no significant reaction with the peptide pegs]. Each nested decamer differs by five amino acids and is labelled between 1 and 103 , corresponding to amino acids $(n \times 5)-5$ to $(n \times 5)+5$ (where $n$ is the decamer number) of the mature $60 \mathrm{kDa}$ CrP of C. trachomatis serovar L1/440/LN (amino acid number 41 onwards). Reactivity is measured as $A_{402}$ at the end of the ELISA assays.

additional proteins (data not shown). Concentrated samples of growth media obtained from expressing cultures were similarly analysed and contained no $60 \mathrm{kDa}$ CrPs. These results indicate that the $60 \mathrm{kDa} C r P s$ were not secreted from $E$. coli nor was there any evidence for cell lysis under inducing conditions. We also conclude that E. coli does not localize the chlamydial $60 \mathrm{kDa} \mathrm{CrPs}$ to its outer membrane when expressed from these vectors.

Transmission electron microscopy on thin sections of IPTG-induced $E$. coli showed that all the recombinant $60 \mathrm{kDa}$ CrPs were expressed as electron-dense insoluble cytoplasmic inclusions. Examples of the $C$. psittaci 'native' $60 \mathrm{kDa} \mathrm{CrP}$ and $C$. pneumoniae gene $1060 \mathrm{kDa}$ $\mathrm{CrP}$ fusion are shown in Fig. 3(b, c). It was possible to recover the large cytoplasmic inclusions of recombinant $60 \mathrm{kDa} \mathrm{CrPs}$ by a simple cell lysis procedure followed by sedimentation of insoluble inclusion bodies. This approach yielded large amounts of crude recombinant chlamydial protein. The yield of crude protein from inclusion body preparations was $0 \cdot 2-0 \cdot 4 \mathrm{~g}$ protein (g wet wt E. coli $)^{-1}$ for non-fusion protein recombinants and 0.4-0.62 g protein (g wet wt E. coli) ${ }^{-1}$ for fusion proteins. Higher yields of protein were produced using freshly transformed host cells. Inclusions prepared in this way were contaminated with some E. coli host proteins. The inclusion bodies were completely soluble only in $2 \%$ SDS in the presence of $5 \% 2$-mercaptoethanol. Solubilization of the inclusions in urea or guanidine and re-precipitation of the protein by dilution removed little of the contaminating $E$. coli proteins. Therefore the recombinant $60 \mathrm{kDa} C \mathrm{Cr}$ s were further purified using preparative SDSPAGE and electroelution.

\section{Immunological studies}

The gel-purified recombinant $60 \mathrm{kDa}$ products were used to immunize rabbits to produce high titre hyperimmune polyclonal antisera Immunoblot analysis of these high titre sera with chlamydial proteins from purified EBs showed genus-reactive properties with the three chlamydial species and the heterologous recombinant 
antigens detectable at serum dilutions up to $1: 10000$. Preimmune sera were negative in these blots as were antiserum against the $E$. coli host strain (JM109) and control antiserum to purified $\mathrm{T} 7$ gene 10 inclusions. Fig. 4 shows an example of the cross-reactivity of the four antisera to the different $60 \mathrm{kDa} C r P$ recombinant products and control antisera to reduced and denatured $C$. pneumoniae EB antigens. These results also clearly demonstrate that the $60 \mathrm{kDa} \mathrm{CrPs}$ of $C$. pneumoniae IOL-207 are expressed as a $60 / 62 \mathrm{kDa}$ 'doublet'.

The molecular specificity of the various antisera was investigated by epitope mapping studies. A series of 110 solid phase decameric peptides overlapping by five amino acids covering the coding sequence for the mature $C$. trachomatis $\mathrm{L} 160 \mathrm{kDa} \mathrm{CrP}$ were synthesized. The results obtained with each antiserum are shown in Fig. 5. All recombinant antisera demonstrated some areas of reactivity interspersed with areas of lower or no reactivity. Reactions with the $C$. trachomatis fusion antisera showed six peptides $(26,43,44,65,94$ and 101) with significant sero-reactivities.

The degree of cross-reactivity of the C. psittaci $60 \mathrm{kDa}$ $\mathrm{CrP}$ antiserum can be seen in Fig. 5(b). As expected from their different primary amino acid sequences, crossreactivity of $C$. psittaci $60 \mathrm{kDa} C \mathrm{PP}$ antiserum with the $C$. trachomatis peptides was reduced compared to the hornologous system. The only significantly reactive peptide common to both $C$. psittaci and $C$. trachomatis antisera was decamer 101 (GEAILSSDTL), which is conserved across the genus. The antisera raised to the two recombinant forms of the $C$. pneumoniae IOL-207 $60 \mathrm{kDa} C r P$ were reacted with the $C$. trachomatis $60 \mathrm{kDa} \mathrm{CrP}$ decameric peptides; the results are shown in Fig. 5(c,d). The two antisera demonstrated very similar patterns of reactivity, indicating the minimal effect of the $\mathrm{N}$-terminal fusion with the $\mathrm{T} 7$ gene 10 protein on the antibody responses elicited to these proteins. Interestingly, the two $C$. pneumoniae antisera reacted similarly to the $C$. psittai $i$ antisera with decamers 100 and 101. Control hyperimmune antisera to bacteriophage T7 gene 10 and to E. coli JM109 showed no reactivity with the $60 \mathrm{kDa}$ CrP decameric peptides.

\section{Surface accessibility of 60 kDa CrP epitopes}

The possibility that the $60 \mathrm{kDa}$ CrPs were surface exposed was investigated by immunogold labelling and trans.mission electron microscopy. Purified chlamydiai preparations from each of the three species that were a mixture of $\mathrm{EB}$ with intermediate bodies and a few reticulate bodies were used in these studies. An antiserum raised to $C$. trachomatis recombinant MOMP expressed in E. coli as insoluble cytoplasmic inclusion bodies (Conlan $e t$ al., 1990) was used as a positive control to demonstrate the technique. The results indicated that none of the antisera to the various $60 \mathrm{kDa}$ CrPs showed any surface labelling in either heterologous or homologous combinations.

Thus the chlamydial $60 \mathrm{kDa} \mathrm{CrPs}$ are potent immunogens in rabbits and possess genus-reactive epitopes as assessed by immunoblot analysis. Further dissection of the anti- body responses using synthetic peptides has indicated a common immunogenic linear peptide (decamer 101) of the $60 \mathrm{kDa} \mathrm{CrP}$ which exhibits genus-reactive properties. This study also shows that the epitopes recognized by the $60 \mathrm{kDa}$ CrP antisera are not accessible on the EB surface in any of the three chlamydial species. To locate the precise position of the $60 \mathrm{kDa} \mathrm{CrP}$ within the chlamydial cell envelope, immunogold labelling experiments will have to be performed on cell sections of EBs using transmission electron microscopy. The technology is currently limited by the quality of embedding resins. Immunogold labelling can be performed on frozen sections although the quality of tissue preservation is still poor, with only the outermost regions of frozen tissue being perfectly preserved. Future work will involve transmission electron microscope studies on frozen sections of purified EBs and the recombinant antisera described here to locate the $60 \mathrm{kDa} \mathrm{CrPs}$ in the chlamydial EB envelope.

\section{ACKNOWLEDGEMENTS}

Many thanks to Ms S. Cox (Department of Electron Microscopy, Southampton General Hospital) for preparation of sections for electron microscopy. We are very grateful to $\mathrm{Dr}$ W. J. Newhall for providing the $60 \mathrm{kDa} \mathrm{CrP}$ monoclonal antibodies. M.W.W. was supported by an MRC research studentship.

\section{REFERENCES}

Allen, J. E. \& Stephens, R. S. (1989). Identification by sequence analysis of two-site posttranslational processing of the cysteine-rich outer membrane protein 2 of Chlamydia trachomatis serovar L2. J Bacteriol 171, 285-291.

Batteiger, B. E. \& Rank, R. G. (1987). Analysis of the humoral immune response to chlamydial genital infection in guinea pigs. Infect Immun 55, 1767-1777.

Batteiger, B. E., Newhall, W. J. V. \& Jones, R. B. (1985). Differences in outer membrane proteins of the lymphogranuloma venereum and trachoma biovars of Chlamydia trachomatis. Infect Immun 50, 480-494.

Bavoil, P., Ohlin, A. \& Schachter, J. (1984). Role of disulphide bonding in outer membrane structure and permeability in Chlamydia trachomatis. Infect Immun 44, 479-485.

Brunham, R. C., Peeling, R., MacLean, I., MacDowell, J., Persson, K. \& Osser, S. (1987). Postabortal Chlamydia trachomatis salpingitis: correlating risk with antigen-specific serological responses and with neutralization. $J$ Infect Dis 155, 749-755.

Carter, M. W., Al-Mahdawi, S. A. H., Giles, I. G., Treharne, J. D., Ward, M. E. \& Clarke, I. N. (1991). Nucleotide sequence and taxonomic value of the major outer membrane protein of Cblamydia pneumoniae IOL-207. J Gen Microbiol 137, 465-475.

Clarke, I. N. \& Lambden, P. R. (1988). Stable cloning of the amino terminus of the $60 \mathrm{kDa}$ outer membrane protein of Chlamydia trachomatis serovar L1. FEMS Microbiol Lett 51, 81-86.

Clarke, I. N., Ward, M. E. \& Lambden, P. R. (1988). Molecular cloning and sequence analysis of a developmentally regulated cysteine-rich outer membrane protein from Chlamydia trachomatis. Gene 71, 307-314.

Coles, A. M., Allan, I. \& Pearce, J.H. (1990). The nucleotide and derived amino acid sequence of the omp2 gene of $C$. trachomatis serovar E. Nucleic Acids Res 18, 6713. 
Collett, B. A., Newhall, W. J. V., Jersild, R. A. Jr \& Jones, R. B. (1989). Detection of surface-exposed epitopes on Chlamydia trachomatis by immune electron microscopy. J Gen Microbiol 135, 85-94.

Conlan, J. W., Ferris, S., Clarke, I. N. \& Ward, M. E. (1989). Surface exposed epitopes on the major outer-membrane protein of Chlamydia trachomatis defined with peptide antisera. J Gen Microbiol 135, 3219-3228.

Conlan, J. W., Ferris, S., Clarke, I. N. \& Ward, M. E. (1990). Isolation of recombinant fragments of the major outer-membrane protein of Chlamydia tracbomatis: their potential as subunit vaccines. $J$ Gen Microbiol 136, 2013-2020.

De La Maza, L. M., Fielder, T. J., Carlson, E. J., Markoff, B. A. \& Peterson, E. M. (1991). Sequence diversity of the 60 -kilodalton protein and of a putative 15-kilodalton protein between the trachoma and lymphogranuloma venereum biovars of Chlamydia trachomatis. Infect Immun 59, 1196-1201.

Everett, K. D. E. \& Hatch, T. P. (1991). Sequence analysis and lipid modification of the cysteine-rich envelope proteins of Chlamydia psittaci 6BC. J Bacteriol 173, 3821-3830.

Fitch, W. M., Peterson, E. M. \& De La Maza, L. M. (1993). Phylogenetic analysis of the outer-membrane-protein genes of Chlamydiae, and its implications for vaccine development. Mol Biol Evol 10, 892-913.

Geysen, H. M., Rodda, S. J., Mason, T. J., Tribbick, G. \& Schoofs, P. G. (1987). Strategies for epitope analysis using peptide synthesis. $J$ Immunol Methods 102, 259-274.

Hatch, T. P., Allan, I. \& Pearce, J. H. (1984). Structural and polypeptide differences between envelopes of infective and reproductive life cycle forms of Chlamydia spp. J Bacteriol 157, 13-20.

Hatch, T. P., Miceli, M. \& Sublett, J. (1986). Synthesis of disulphidebonded outermembrane proteins during the developmental cycle of Chlamydia psittaci and Chlamydia trachomatis. J Bacteriol 165, 379-385.

Kyte, J. \& Doolittle, R. F. (1982). A simple method for displaying the hydropathic character of a protein. $J$ Mol Biol 157, 105-132.

Laemmli, U. K. (1970). Cleavage of structural proteins during the assembly of the head of bacteriophage T4. Nature 227, 680-685.

Lambden, P. R., Everson, J. S., Ward, M. E. \& Clarke, I. N. (1990). Sulfur-rich proteins of Chlamydia trachomatis: developmentally regulated transcription of polycistronic mRNA from tandem promoters. Gene 87, 105-112.

Melgosa, M.P., Kuo, C.-C. \& Campbell, L. A. (1993). Outer membrane complex proteins of Chlamydia pneumoniae. FEMS Microbiol Lett 112, 199-204.

Newhall, W. J. V., Batteiger, B. \& Jones, R. B. (1982). Analysis of the human serological response to proteins of Chlamydia trachomatis. Infect Immun 38, 1181-1189.

Newhall, W. J. V. \& Basinski, M. B. (1986). Purification and structural characterization of chlamydial outer membrane proteins. In Cblamydial Infections, Proceedings of the 6th International Symposium on Human Chlamydial Infections, pp. 93-96. Edited by D. Oriel, G. L. Ridgway, J. Schachter, D. Taylor-Robinson \& M. E. Ward. Cambridge: Cambridge University Press.

Osborn, M. J. \& Munson, R. (1974). Separation of the inner (cytoplasmic) and outer membranes of Gram-negative bacteria. Methods Enzymol 31, 642-653.

Peterson, E. M., Markoff, B. A. \& De La Maza, L. M. (1990). Characterization of a neutralizing, species specific epitope of the MOMP of Chlamydia trachomatis. In Chlamydial Infections, Proceedings of the 7 th International Symposium on Human Chlamydial Infections, pp. 77-80. Edited by W. R. Bowie, H. D. Caldwell, R. P. Jones, P. Mårdh, G. L. Ridgway, J. Schachter, W. E. Stamm \& M. E. Ward. Cambridge: Cambridge University Press.

Pickett, M. A., Everson, J. S. \& Clarke, I. N. (1988). Chlamydia psittaci ewe abortion agent: complete nucleotide sequence of the major outer membrane protein gene. FEMS Microbiol Lett 55, 229-234.

Salari, S. H. \& Ward, M. E. (1981). Polypeptide composition of Cblamydia trachomatis. J Gen Microbiol 123, 197-207.

Smith, P. K., Krohn, R. I., Hermanson, G. T., Mallia, A. K., Gartner, F. H., Provenzano, M. D., Fujimoto, E. K., Goeke, N. M., Olson, B. J. \& Klenk, D. C. (1985). Measurement of protein using bicinchoninic acid. Anal Biochem 150, 76-85.

Studier, F. W. \& Moffatt, B. A. (1989). Use of bacteriophage T7 RNA polymerase to direct selective high-level expression of cloned genes. J Mol Biol 189, 113-130.

Wagar, E. A., Schachter, J., Bavoil, P. \& Stephens, R. S. (1990). Differential human serological response to two 60,000 molecular weight Chlamydia trachomatis antigens. J Infect Dis 162, 922-927.

Watson, M. W., Lambden, P. R., Ward, M. E. \& Clarke, I. N. (1989). Chlamydia trachomatis $60 \mathrm{kDa}$ cysteine rich outer membrane protein: sequence homology between trachoma and LGV biovars. FEMS Microbiol Lett 65, 293-298.

Watson, M. W., Lambden, P. R. \& Clarke, I. N. (1990a). The nucleotide sequence of the $60 \mathrm{kDa}$ cysteine rich outer membrane protein of Chlamydia psittaci strain EAE/A22/M. Nucleic Acids Res 18, 5300 .

Watson, M. W., Al-Mahdawi, S., Lambden, P. R. \& Clarke, I. N. (1990b). The nucleotide sequence of the $60 \mathrm{kDa}$ cysteine rich outer membrane protein of Cblamydia pneumoniae strain IOL-207. Nucleic Acids Res 18, 5299.

Zhang, Y.-X., Stewart, S. J. \& Caldwell, H. D. (1989). Protective monoclonal antibodies to Chlamydia trachomatis serovar- and serogroup-specific major outer membrane protein determinants. Infect Immun 57, 636-638.

Received 31 December 1993; accepted 9 March 1994. 